\title{
Welfare Employment and Its Impact on the Agricultural Sector Workforce in Trinidad, West Indies
}

\author{
Marcus N. A. Ramdwar ${ }^{1}$, Wayne Ganpat ${ }^{2} \&$ Leevun A. R. Solomon ${ }^{2}$ \\ ${ }^{1}$ Biosciences, Agriculture and Food Technologies, ECIAF Campus, The University of Trinidad and Tobago, \\ Centeno, Trinidad and Tobago \\ ${ }^{2}$ Faculty of Science and Agriculture, The University of the West Indies, St, Augustine Campus, Trinidad and \\ Tobago \\ Correspondence: Marcus N. A. Ramdwar, Biosciences, Agriculture and Food Technologies, ECIAF Campus, \\ The University of Trinidad and Tobago, Centeno, Trinidad and Tobago. Tel: 1-868-710-6678. E-mail: \\ marcus.ramdwar@utt.edu.tt
}

Received: August 22, 2020

Accepted: October 25, $2020 \quad$ Online Published: November 15, 2020

doi:10.5539/jas.v12n12p49

URL: https://doi.org/10.5539/jas.v12n12p49

\begin{abstract}
The agricultural sector in Trinidad and Tobago is characterized by a labor shortage. A qualitative research design was used to investigate the impact of a national welfare employment program, on the agriculture labor sector. The study recruited $n=19$ Community-Based Environmental Protection and Enhancement Program (CEPEP) employees, $\mathrm{n}=10$ farmers and $\mathrm{n}=7$ agricultural professionals for in-depth interviews and focus group sessions. A review was conducted of newspaper articles and national budget statements for content related to CEPEP and agriculture. A thematic analysis was conducted to establish themes from the data gathered from the participants and from the media review. The themes emerged were "CEPEP's benefits to agriculture", "Labor shortages in Agriculture", "Convenience Employment" and "Challenges to CEPEP in Agriculture". The study concludes that welfare employment can be incorporated into the development agenda for agriculture in Trinidad and Tobago once the issues of capacity building, retooling and mentorship, wage adjustments are factored into a structured program.
\end{abstract}

Keywords: CEPEP, de-agriculturalization, agriculture, welfare-labor

\section{Introduction}

The Republic of Trinidad and Tobago has the most industrialized economy in the English-speaking Caribbean. Nevertheless, it is classified as a developing country according to International Monetary Fund (2012). The economy of Trinidad and Tobago is highly dependent on its energy sector and the revenues obtained from the oil and gas industries are used to fund a number of the country's social welfare programs. Hosein and Tewarie (2004) in their technical paper on Dutch disease in the wake of a second oil boom in Trinidad and Tobago noted that "although natural resource booms play an important role in helping to alleviate some of the traditional obstacles to development, including; bridging fiscal deficits, savings and investment gaps and providing a rapid inflow of foreign exchange, it also brought adverse effects". One such "adverse" effect may be the consequential shift away from agricultural employment to state funded welfare employment programs or make-work programs as they are locally called.

The Community-Based Environmental Protection and Enhancement Program (CEPEP), established in 2002, is one such social make-work program that is highly dependent on energy generated revenues for funding. According to official documents, the objectives of the CEPEP program are: (i) to foster the empowerment of communities to improve the conditions of the local physical environment; (ii) to facilitate the expansion of employment opportunities for the benefit of semi-skilled and un-skilled persons within their communities; and (iii) to enable the creation of opportunities for the establishment and development of small businesses. Under CEPEP, contracts are awarded for a wide range of projects such as cleaning and maintenance of green areas, clearing of drains and areas affected by flooding, roadside grass maintenance and general environmental needs. Nevertheless, CEPEP, is often regarded as a "wastage of taxpayers' money" by economists. For instance, Douglas (2007) in a newspaper article, "CEPEP $\$ 378$ M Spree", referred to the Auditor General's special report which criticized the Government's budget of TT $\$ 378 \mathrm{M}$ allocated to the CEPEP program for a two-year period. The article reported 
that one of the issues with the program was with the lack of accountability and transparency surrounding the organization. In spite of this, the annual monetary allocation to CEPEP remains high and in 2018 was TT 447M.

Studies have linked economic advancement with a reduction in the dependency of agriculture as a livelihood as people shift to more productive non-farm activities (Chand \& Srivastava, 2014; Venkatesh, 2013). Arguably, the mobility of unskilled and semi-skilled people into make-work social programs may not be considered more productive than farming activities, however, it can potentially influence the agricultural workforce. Noteworthy, the food import bill for Trinidad and Tobago over the period 2003 to 2016, was an estimated US\$8.91 billion or TT\$56.9 billion (Government of Trinidad and Tobago, 2018). According to the 2013 Caribbean Community (CARICOM) reports, this figure represents $20 \%$ of the region's overall food import bill which is only $1 \%$ behind the economy with the largest imports, Jamaica. This dependence on food import implies vulnerability to external food supply shocks which are likely to increase because of rising volatility in food markets, related to world issues such as climate change, resource scarcity (land, water etc.), rising prices for energy and agro-chemicals, increased demand for bio-fuels, and population growth (World Bank, 2008). The vulnerabilities to food insecurity therefore, must be considered in all small island states (SIDs) and as such, sustaining a productive national agricultural work-force is necessary regardless of economic growth.

It was estimated for the period of January to September, 2017 that agriculture, forestry, hunting and fishing industries accounted for a 3.6 percent (22,900 persons) of Trinidad and Tobago's labor force (Government of the Republic of Trinidad and Tobago, 2018). Moreover, the agriculture sector, in Trinidad and Tobago is characterized by low wages for long hours of laborious work. As a result, one of the main complaints in the agricultural sector is lack of labor (National Training Agency, 2015). Similarly, the introduction of CEPEP into rural communities had a further effect of attracting labor from farms into the social program. Notwithstanding, the basic wages for CEPEP is less (TTD $89 \approx$ USD 13.20 per day) when compared to farm related labor of an average of TTD $200 \approx$ USD29.67 per day, the tradeoff of shorter work days and less laborious tasks is attractive. Some farmers have responded by increasing the daily wage for workers, however, many persons still decline this incentive because of the relatively long hours of work. It was reported by Fraser (2014) that, "people in agriculture [farmers], especially in rural communities, were among the first to raise their voices about losing labor to CEPEP". Similarly, CEPEP was hurting the private non-agriculture sector since workers prefer to work with CEPEP because in terms of monetary value, they work less hours in CEPEP when compared to the private sector (Sorias, 2014). Moreover, the Inter-American Development Bank (IDB) was also critical of social programs such as CEPEP suggesting that these programs were causing problems for Trinidad and Tobago citing disincentives to work and overall lack of productivity as foreseeable problems for the country (Khan, 2014).

Globally, there have been many concerns related to agricultural labor shortages and principal among them is, "the strong pull effects of other sectors on agricultural labor" (Tocco, Davidova, \& Bailey, 2012). The reality of a shrinking agricultural work force resulting from employment preferences in other sectors as well as in social make-work programs will have an impact on agricultural development. Wenner, Bollers \& Hosein (2018) in the publication "The Dutch Disease Phenomenon and Lessons for Guyana: Trinidad and Tobago's Experience" has demonstrated the impact of make-work programs on agriculture employment. It was revealed that there was a forty-three percent (43\%) contraction in agriculture employment for the period 2001 to 2008 with a simultaneous increase in employment (16.3\%) in the social make-work programs.

The use of energy revenues to fund make-work programs in non-agricultural activities, can severely impact agriculture. Interestingly, Lewis (1954), some sixty-five (65) years ago, pointed out that "industrial and agrarian revolutions always go together" and noted that "economies in which agriculture is stagnant do not show industrial growth." Timmer (2005) noted that the relationship between food security and economic growth is mutually reinforcing, and as such explicitly identifies that the agricultural sector plays a critical and dynamic role towards the achievement of economic growth, poverty reduction and stability of the domestic food system. Notwithstanding this, as an employment strategy for the most socially vulnerable, the shift of labor from the low productive agriculture sector to the more productive industrialized sectors has increased the level of national income for Caribbean countries. In the global scenario, the energy sector in Trinidad can be regarded as highly vulnerable (Becken \& Lennox, 2012) and as such the agriculture sector must be sustained as the primary sector for meaningful employment and for future food security. It is also worth noting that the agriculture, forestry and the fisheries industry's Gross Domestic Product (GDP) for the period 2015 to 2018 was estimated to be an average of $0.4 \%$ (Government of the Republic of Trinidad and Tobago, 2018) further revealing the insignificant contribution of agriculture to the economy.

The industrial development in Trinidad and Tobago and other islands in the Caribbean should not occur with agricultural neglect. Trinidad and Tobago's economy is dependent on oil and gas prices set elsewhere and drops 
in prices have severe trickle down impact on national development and on the standard of living of nationals. While, many issues impact the sustainability of food production, this paper presents a situational analysis of the impact of a community-based welfare program on the agricultural sector in Trinidad.

The study is framed by the following specific objectives: (i) to provide a review of the influence of the social make-work program on the labor supply in the agriculture sector; (ii) to examine the financial allocations to CEPEP in comparison to the agriculture industry for the period 2008-2019; (iii) to provide recommendation for incorporating an existing social make-work program into the agricultural workforce in Trinidad.

\section{Methodology}

A qualitative approach was principally employed for this study as it offers an effective way to provide a detail understanding into human behaviour regarding emotions, attitudes, and experiences (Tong et al., 2012); all of which are relevant concepts in this study. Triangulation by data source and by method was used to improve the trustworthiness of the study (Denzin \& Lincoln, 1998; Miles \& Huberman, 1994). Triangulation by mixing data or methods provides a diverse viewpoint which is thought to help in validating the claims that might arise from qualitative studies (Olsen, Holborn, \& Haralambos, 2004).

Purposive sampling was employed for the selection of participants. This involves identifying and selecting individuals or groups of individuals that are especially knowledgeable about or experienced with a phenomenon of interest (Cresswell \& Plano Clark, 2011). The issue with the purposive method however, is that the researcher exercises judgment on the informant's reliability and competency (Dolores \& Tongco, 2007). With regards to the present study, the participants also gave consent for background checks to be conducted to ensure that they met the criteria for the research.

Confidentiality and identity for all participants in the study were protected in the transcribed interviews, the data analysis process, and in the reporting of the findings. All participants had the opportunity to ask questions about the study, and they were informed that they had the right to decline to answer any questions or withdraw from the interview at any time. A moral and ethical effort was made to ensure the protection of the human subjects who participated in the research (Naimi, 2007).

\subsection{Methods of Data Collection}

The specific instruments employed for the study were semi-structured, in-depth interviews, focus groups and document analysis. The participants for the study comprised of three (3) audiences from three (3) independent groups of primary stakeholders: (i) agricultural professionals, (ii) farmers, and (iii) CEPEP workers. The order of the participant engagement for information and data gathering was agricultural professionals, farmers, and then CEPEP workers. Table 1 provides a summary of the number of participants and the qualitative research tools used for gathering information.

Table 1. Outline of participants and the tools used for gathering information

\begin{tabular}{llll}
\hline Participant Pool & Workplace & Tool & Number \\
\hline Agricultural Professionals & Public \& Private Sector & Semi-structured questionnaire & 7 \\
Farmers & Farming enterprises in Trinidad & Semi-structured questionnaire & 10 \\
CEPEP & Communities in Trinidad & Focus Group Sessions x 2 & 19 \\
\hline Total & & & 36 \\
\hline
\end{tabular}

\subsubsection{Agricultural Professionals}

A purposive sampling approach was used to select agricultural professionals $(n=7)$ who had up to tertiary level education and were considered experts in the discipline of agriculture. A semi-structured questionnaire was used to elicit information related to their views on CEPEP as a social make-work program and about the benefits and challenges to incorporating the CEPEP work force into the agricultural sector. The duration of each interview was approximately forty (40) minutes.

\subsubsection{Farmers}

A purposive sampling approach was employed for the selection of full-time farmers $(n=10)$ from ten farming areas in Trinidad in order to obtain information related to their current labor issues, their perception of the CEPEP program and their views on CEPEP labor being utilized in farming enterprises. The duration of each farmer interview was approximately thirty-five (35) minutes. 


\subsubsection{Focus Groups}

A focus group was conducted following the procedures of Krueger and Casey (2000) for two independent (2) sessions with CEPEP employees. The participants were asked to share their views on their personal experiences as a CEPEP employee.

A purposive sampling technique was used to select two (2) groups to participate in focus group sessions; eight (8) CEPEP employees from an urban (non-farming district) and eleven (11) CEPEP employees from a rural (a farming district). The specific site for the selection of participants as well as the location of the focus group sessions were withheld to preserve the possible identification of CEPEP groups and the members who would have participated in the study. Permission to interview the CEPEP members was provided by the respective supervisors in both areas. The supervisor at each site provided the daily roster schedule from which participants were randomly selected. The supervisor gave assurance to the CEPEP employees that they would in no way be negatively impacted for participation and also indicated to them that their participation was voluntary. The selection criteria for the participants for the focus groups were based on individuals who were working with CEPEP for a minimum of one (1) year and were considered to be a general unskilled employee.

Guiding questions were related to obtaining current CEPEP employee's sentiments about (i) their experiences as a CEPEP employee, (ii) the potential role of CEPEP workers for supporting agricultural development in Trinidad and Tobago and, (iii) the possible challenges that CEPEP employees may face working within the agricultural sector. The participants were also encouraged to provide details of their experiences as an employee of in CEPEP Participants were additionally asked to comment on the option of CEPEP employees to be included within the agriculture sector.

The moderator for the focus group was supported by one note taker who recorded the discussions and other field notes. Each group was assured of confidentiality and anonymity and made aware that the session was being audio recorded. Each focus group session lasted approximately sixty (60) minutes. An immediate debriefing session was done with the moderator to make a preliminary identification of the main issues that emerged from the individual focus group sessions. Likewise, the audio files were transcribed by the researcher and compared with the detailed field notes.

\subsubsection{Online Document Gathering and Analysis}

Newspaper articles were obtained from the website of three (3) independent media houses in Trinidad and Tobago: Express, Newsday and Guardian. The website contained a chronological database of archived articles where stories and reports pertinent to CEPEP were searched for the period 2012 to 2017. The key words, "CEPEP" and "Agriculture", were used to source electronic versions of articles. Significant and relevant articles to the study were identified and the source, title and date were tabulated. In the end, a total of twelve (12) articles where gathered for the analysis. The national annual budget statements for the fiscal period 2008-2019 were sourced from the Ministry of Finance's website. Information regarding the projected oil price (USD per barrel), the projected natural gas price (USD per MMBtu), the total projected energy revenue, the CEPEP fiscal allocation, and the allocation to the Ministry of Agriculture (Land and Fisheries) were extracted from each budget statement. In this manner, the information for the previously-mentioned period was then tabulated in order to evaluate the allocation trends of CEPEP in comparison to the agriculture sector. Percentages were used to examine allocation to CEPEP in relation to agriculture for comparative purposes.

\subsection{Analysis of Information Sources: Focus Groups, Interviews and Newspaper Articles}

\subsubsection{Thematic Analysis: Impact of CEPEP on the Labor Supply in the Agricultural Sector}

Thematic analyses were applied to the following textual data to search for themes: (i) transcribed interviews and (ii) focus groups, and (iii) newspaper articles. The procedure for the thematic analysis for the data of this study followed the step-by-step procedure outlined by Braun and Clarke (2006). All sources of data from each data capturing method were reviewed and the themes were derived as they emerged from the data. According to Rice and Ezzy (1999), the identification of themes involves a process of "reading and re-reading the data corpus". The emerged themes are essential for describing the phenomenon being investigated (Daly, Kellehear, \& Gliksman, 1997). The QSR NVivo 8 software was used to manage and organize the data, facilitating the identification of themes. However, it must be noted that the QSR NVivo 8 software is only an aid to the organization of the material and is not in itself an interpretive device (King, 2004).

In reporting the emerging themes, supportive illustrative verbatim statements from the participant or extracts from the newspaper are written in italics surrounded by double quotation marks. The statements were used to depending the understanding of the emerged themes by providing evidence from the participant's voice and from 
the newspaper extracts. A concept map was created to organize and present the emerged themes. This would form the synthesis of the discussion. Convergences of consensus among the methodologies were evaluated to assess the reliability of emerged themes.

\section{Results}

\subsection{Profile of Participants}

The seven (7) agricultural professionals interviewed were all holders of postgraduate qualifications in agriculture; four (4) were qualified at the Master's level and three (3) at the Doctor of Philosophy level. The number of years of service working within the agricultural sector ranged from fifteen (15) years of service to thirty (30) years. All of the agricultural professionals had both public and private sector experiences.

The ten (10) farmers selected for this study were from various farming areas throughout Trinidad. All the farmers were men above forty (40) years of age, self-employed and had over fifteen (15) years of active farming experience. Eight were involved in crop production and two (2) in livestock farming. The farmers were primarily dependent on family and community labor for farming responsibilities such as the cultivation of vegetables, roots crops and cocoa and the daily management of animals. The area of the crops under cultivation by the farmers interviewed ranged from 0.5 ha to 6 ha. The livestock farmers interviewed were a sheep farmer and a pig farmer each with over one-hundred heads of animals.

The nineteen (19) CEPEP participants from the two focus group sessions comprised; eight (8) participants from the Port of Spain (urban) District (Focus Group 1) and eleven (11) participants from the Felicity farming District (Focus Group 2). There were eleven (11) females and eight (8) males, the majority of the participants were over thirty-one (31) years of age with only one participant within the range of 46-50 years of age. Nine of the participants were employed as a CEPEP employee for 5 years or over. Seven participants indicated that CEPEP was their only source of income.

\subsection{Thematic Analysis}

The results of the thematic analysis were structured in terms of the main themes which emerged from the information obtained from the newspaper, professionals in agriculture, CEPEP workers and full-time farmers. The emerging themes identified in the analysis of the data corpus are: (i) "CEPEP Potential Benefits to Agriculture", (ii) "Labor Shortages in Agriculture", (iii) "Convenience Employment" and (iv) "Challenges Associated with CEPEP employment in Agriculture". Although each theme is presented and expanded on separately, the themes are not mutually exclusive. The complexity of the topic and broad nature of the research question created themes which were interlinked. The illustrative extracts cited for the purpose of this paper include only a representative sample of participant responses and the newspaper articles reviewed. They are used to provide additional support for the themes identified.

\subsubsection{Theme 1: CEPEP Benefits to Agriculture}

There was a consensus among the agricultural professional and farmers alike that CEPEP labor can be a useful addition to the agricultural workforce. Likewise, it was also the opinion of these two particular groups that the shortage of farm workers was negatively impacting agricultural productivity in Trinidad and that CEPEP's involvement with agriculture can help improve productivity and also reduce the already high food import bill. There was an expressed view among all participants in this study that there should be some consideration for a special unit in CEPEP for individuals who would prefer to work in agriculture. There was also evidence of this in the newspaper articles reviewed.

Illustrative Extracts for Theme 1: CEPEP Benefits to Agriculture:

(1) “CEPEP labor will be beneficial to farmers". (Male, 45, CEPEP worker, Felicity; Male, 49, Agricultural Professional)

(2) "CEPEP can be a mechanism for government to share agricultural labor cost with the farmers, the government pay part and the farmer pays part" (Male, 54, Agricultural Professional)

(3) "People have land but do not have the capacity to pay labor, CEPEP can assist with providing labor to farmers". (Male, 58, Farmer, Orange Grove).

(4) "Trinidad have enough land and with CEPEP workers we can reduce the food import bill". (Male, 63, Farmer, Waller Field)

(5) It's all good for farmers to have CEPEP workers but they should be given some form of training before they come". (Male, 56, Farmer, Maloney, Trinidad) 
(6) "A special unit should be set up in CEPEP for people interested in working on farms and those individuals should be trained and receive a higher rate of pay when compared to the regular CEPEP worker". (Male, 37, CEPEP Employee, Rural District)

(7) "The memorandum of understanding is aimed at developing a strategic relationship between CEPEP and the ministry [... of Food Production now] to facilitate efficient food production and food security through the provision of skilled labor". (Trinidad Guardian Newspaper, July 4, 2013)

(8) Transform part of CEPEP into a farmpep program to boost the industry". (Trinidad Guardian Newspaper, March 23, 2014)

\subsubsection{Theme 2: Labor Shortages in Agriculture}

There was an explicit view by agricultural professionals and farmers that Trinidad and Tobago was currently experiencing a labor crisis within the agricultural sector. Some of the participants indicated that mechanization, not CEPEP labor, was key to addressing the labor issue, however, it was indicated that with mechanization technical training and support was urgently required if it was to be successful. The participants indicated that CEPEP was a contributory factor for the labor shortage not only for the agricultural work-force but for other sectors as well. One farmer indicated that obtaining labor was so difficult in Trinidad that he had to resort to employing persons from other countries in the region, for example Guyana, St. Vincent and Grenada. There was also a general view that the Venezuelan immigrants could help to alleviate the labor shortage in agriculture. There was a strong view among all participants and from articles in the national newspapers, that efforts should be directed to increasing agricultural productivity given the instability of oil prices coupled with the high food importation bill. The challenge however was to get people to want to work in the sector. There have been attempts to incorporate CEPEP workers into the agricultural work-force but there has been no significant relief to the farmers in their plight to find labor for their farming enterprises.

Illustrative Extracts for Theme 2: Labor Shortages in Agriculture:

(1) "[The] Agricultural community was affected by a depleting workforce because farmers were getting older and their children were not interested in agriculture". (Male, 43, Agricultural Professional)

(2) "Mechanization is the way to go to deal with the labor shortage but we need to get it right and have the technical support and agricultural extension support for the technology". (Male, 59, Agricultural Professional).

(3) The farmers go to Guyana and bring back people who are willing to work on farms for $\$ 150$ to $\$ 200$ per day". (Male, 70, Agricultural Professional)

(4) "Some CEPEP workers have been trained to work in agriculture but they still prefer to work the conventional CEPEP task of cutting grass, cleaning pavements and drains". (Male, 31, CEPEP employee, Rural District).

(5) "Despite the fact that agriculture can provide a viable source of income, we are just not interested in that kind of employment". (Male, 43, CEPEP employee, Urban District)

(6) "CEPEP employment can actually be a more sustainable from of employment compared to working in the agricultural sector given the inconsistency in the characteristic small-scale productivity of Trinidad farmers". (Agricultural Professional, 34)

(7) "Before my wife and children would help me plant the crops, now my wife working CEPEP and one of my two children in university and the other graduated last year [2018] as a doctor ... labor for my garden [crop production enterprise] is difficult, it is I alone". (Farmer, 58, Fishing Pond).

(8) "As long as there is CEPEP that will always be a restrictive factor for agriculture. Nobody will want to go into agriculture because they will want to join CEPEP.” (Trinidad Express, September 17, 2013)

(9) "Several advertisements placed in the print media seeking laborers for the 100-acre Chaguaramas Farm in Tucker Valley, has yielded little or no results in the last three months". (Trinidad Guardian Newspaper, March 23, 2014)

(10) "Locals have been gravitating towards CEPEP, which requires less hours of work for a full day's pay. This is the culture we are accepting and encouraging. People just want everything easy. Many of the farmers have complained to the association [National Food Crop Farmers' Association] but this is a matter for the ministry to deal with". (Trinidad Guardian Newspaper, March 23, 2014) 
(11) “CEPEP cannot be allowed to exist as a disincentive to production or sustainable employment". (Trinidad Express, September 3, 2014)

(12) "Government social programs like CEPEP have been taking away private sector of jobs". (Trinidad Express, January 20, 2015)

(13) “One farmer paid $\$ 400$ a day per worker to harvest peppers but those workers quit as soon as the dry season set in, refusing to work in warm outdoor conditions ... they rather work KFC ... for $\$ 67.50$ a day". (Trinidad Guardian Newspaper, June 26, 2015)

(14) "Shortage of labor in the cocoa industry can be addressed by training and employing workers attached to the Community-Based Environmental Protection and Enhancement Program (CEPEP) in rural areas, as well Venezuelan migrants". (Trinidad Newsday, June 11, 2019)

3.2.3 Theme 3: Convenience Employment

All of the CEPEP participants indicated that it was convenient for them to be employed in the program. The convenience was related to the short working hours; about four hours in the morning. Some of the CEPEP participants indicated that because of early morning working hours they were able to have two jobs. In some cases, mothers in the program indicated that it was convenient for them to obtain some money and still have the time to look after their families. A few participants indicated that if they were not employed in CEPEP there would have been doing something illegal and found that the program was able to prevent them from entering a life of crime. The participants all expressed satisfaction with the task required of them and did feel that they were making a contribution to the community. All participants expressed a desire for more pay.

It was expressed view among the agricultural professionals and some of the famers that CEPEP was a "make-work" strategy to address unemployment and for political support.

Illustrative Quotations for Theme 3: Convenience Employment:

(1) "The successive governments use CEPEP to artificially adjust the unemployment rate". (Male, 58, Agricultural Professional)

(2) “CEPEP is a government tool to win elections". (Male, 60, Farmer, Orange Grove)

(3) "Working in CEPEP benefits me, because of the short hours of work, I am able to be at home early enough to do my household chores and prepare food for my family when they come from work and school". (Female, 42, CEPEP employee, Urban District)

(4) "I am able to work another job after I am done with my task for the day with CEPEP". (Male, 32, CEPEP employee, Urban District)

(5) "CEPEP for me is easy work, I much rather be doing this than any other jobs, I am able to be free and relax for most of the day unlike other jobs". (Male, 40, CEPEP employee, Rural District)

(6) "I work CEPEP and I then go to work in a restaurant in the evening time, CEPEP alone is not enough to sustain me, but it is good enough to get some bills out the way". (Female, 31, CEPEP employee, Urban District)

(7) "Farming is hard work, I would rather work CEPEP and another job than to work in agriculture. Agriculture is hard work". (Male, 34, CEPEP employee, Rural District).

\subsubsection{Theme 4: Challenges to CEPEP in Agriculture}

There was a collective view among all participants that there would be some challenges with integrating CEPEP into the agricultural sector. There was consensus among both the agricultural professionals and the farmers that agriculture is dependent on a skilled workforce. It was suggested that training was required before workers are introduced into a farming environment. It was highlighted that the rural farming demographic would be the only areas where the CEPEP employee could become engaged in agricultural activities. There was consensus that it would be very difficult to change the mindset of the CEPEP workers to be employed into the agricultural sector. It was suggested by the agricultural professionals that only persons who were interested in agriculture should be considered to be involved in the sector rather than to force anyone to be involved in agriculture. There was a consensus among all the agricultural participants that although CEPEP workers offers the opportunity for increasing the already dwindling agricultural workforce. It was suggested that farmers should contribute to the payment of the CEPEP workers. 
Illustrative extracts for Theme 4. Challenges to CEPEP in Agriculture:

(1) "CEPEP for agriculture would only be feasible for agricultural districts and even then, it may still be difficult to get people to want to work in agriculture". (Male, 56, Agricultural)

(2) "More pay for working in Agriculture can make it attractive". (Male, 48, Agricultural Professional)

(3) "Given the number of hours they work for in CEPEP and the kind of work they do they are better paid than working on a farm". (Male, 53, Agricultural Professional)

(4) "The government cannot be expected to provide free CEPEP labor to the farmers, there must be some partnership especially since more pay would be expected for the CEPEP workers involved in agriculture". (Male, 58, Agricultural Professional)

(5) "You cannot simply take a CEPEP workers and put them into agriculture". (Agricultural Professional, 58)

(6) "Agriculture is considerably hard work which requires long hours and it may be unattractive to the CEPEP workers". (Male, 58, Farmer)

(7) "CEPEP workers would need farm specific type of agricultural training depending on the type of farm". (Male, 58, Farmer, Maloney)

(8) "I am comfortable working for CEPEP, the pay is small but I can get by". (Female, 33, CEPEP employee, Rural District)

(9) "I have no interest in working in agriculture, I rather my small pay for my small labor". (Female, 34, CEPEP worker, Rural District)

(10) "Working in agriculture is too much hard work compared to what I do know". (Male, 35, CEPEP employee, Urban District)

\subsection{Assessment of Theme Reliability}

There was consensus with the integrated methods used for the themes derived. The assessment of consensus among the participants was derived using the procedures outlined by Onwuegbuzie, Leech, and Collins (2010). Table 2 summaries the consensus among participant stakeholders for themes derived and evidence of the theme's existence in the newspaper articles reviewed. The themes emerged were reflected strongly by each stakeholder groups and were evident in the newspaper suggesting newspaper credibility in reporting the idea of CEPEP workers possible involvement with agriculture.

Table 2. Consensus assessment among participant stakeholders for themes derived and evidence of theme existence in the newspapers evaluated

\begin{tabular}{lllll}
\hline \multirow{2}{*}{ Theme } & \multicolumn{3}{c}{ Number of participants } & \multirow{2}{*}{ Newspaper Articles } \\
\cline { 2 - 4 } & Agricultural Professionals & Farmers & CEPEP Workers & \\
\hline Benefits to Agriculture & $7 / 7$ & $10 / 10$ & $17 / 19$ & Evident \\
Labor shortages in Agriculture & $7 / 7$ & $10 / 10$ & - & Evident \\
Convenience Employment & $7 / 7$ & $4 / 10$ & $19 / 19$ & Evident \\
Challenges to CEPEP in Agriculture & $7 / 7$ & $7 / 10$ & $16 / 19$ & Evident \\
\hline
\end{tabular}

\subsection{National Annual Budget Statements}

The information extracted from the annual national budget statements is presented in Table 3. The fiscal allocation to CEPEP in most instances was just below half of the fiscal allocation to agriculture for 2019, 2016, $2015,2014,2013$, and 2009. It was observed that this was independent to the value of the total energy revenue for the mentioned years. The allocation to CEPEP was greater than 50 percent of the allocation to agriculture in 2018,2017 and 2011 corresponding to $83.3 \%, 55.84 \%$ and $51.38 \%$ respectively. 
Table 3. Projected energy revenue, CEPEP and agriculture sector fiscal allocation 2008-2019

\begin{tabular}{|c|c|c|c|c|c|c|}
\hline \multirow{2}{*}{ Year } & \multicolumn{2}{|c|}{ Projected Oil and Gas Prices } & \multicolumn{3}{|c|}{ \$TT Billions } & \multirow{2}{*}{$\begin{array}{l}\text { Cepep Percentage of } \\
\text { Agriculture Allocation }\end{array}$} \\
\hline & Oil USD/Barrel & Gas USD/MMBtu & Energy Revenue & CEPEP & Ministry of Agriculture & \\
\hline 2019 & 65 & 2.75 & 9.52 & 0.38 & 0.78 & $48.71 \%$ \\
\hline 2018 & 52 & 2.75 & 6.40 & 0.45 & 0.54 & $83.30 \%$ \\
\hline 2017 & 48 & 2.25 & 2.56 & 0.43 & 0.77 & $55.84 \%$ \\
\hline 2016 & 45 & 2.75 & 5.45 & 0.36 & 0.83 & $43.37 \%$ \\
\hline 2015 & 80 & 2.75 & 21.22 & 0.61 & 1.33 & $45.86 \%$ \\
\hline 2014 & 80 & 2.75 & 23.37 & 0.53 & 1.32 & $40.15 \%$ \\
\hline 2013 & 80 & 2.75 & 20.04 & 0.58 & 1.3 & $44.61^{`} \%$ \\
\hline 2012 & 75 & 2.75 & 18.10 & 0.49 & 1.95 & $25.13^{`} \%$ \\
\hline 2011 & 65 & 2.75 & 15.20 & 0.37 & 0.72 & $51.38 \%$ \\
\hline 2010 & 55 & 2.75 & 36.66 & 0.09 & 0.73 & $12.30 \%$ \\
\hline 2009 & 70 & 4 & 49.47 & 0.30 & 0.67 & $44.78 \%$ \\
\hline 2008 & 50 & 3.55 & 40.38 & 0.25 & 0.72 & $34.72 \%$ \\
\hline
\end{tabular}

Note. Compiled from Trinidad and Tobago (TT) Budget statement for the period 2008-2019. 1 USD = 6.78 TTD.

In 2010, oil was sold at US\$ 55/barrel, earning TT\$36.66 billion in revenue. However, when price fell marginally to US\$52/barrel in 2018, the country was only able to earn TT\$ 6.4 billion. This suggests that a $5.45 \%$ drop in the projected oil price lead to an $82.54 \%$ projected fall in revenues. Over the last decade there has been a general decline in the projected energy revenues in Trinidad and Tobago. However, some buoyancy was observed in the latter years, 2017 to 2019. Allocations to the CEPEP fluctuated over the decade with the lowest allocation of $\$ 0.09$ billion in 2010 and the highest of $\$ 0.79$ billion in 2012. However, in relation to energy revenues over the last 5 years, although energy revenues declined generally, the CEPEP allocation still benefited relatively in 2015, 2017 and 2018. Although energy revenues fell between 2014-2017, allocations to the Ministry of Agriculture remained constant between 2013-2015. However, a decline in fiscal support was noted in the succeeding period 2015-2018. Simultaneous to the projected increased in energy revenues in 2019, the allocation to the Ministry of Agriculture increased.

\section{Discussion and Conclusion}

It was the position of Sir Arthur Lewis, a development economist from the West Indies in 1950, that agricultural development must continue alongside industrial development and that "neither can go very far unless the other is occurring at the same time" (Williams \& Smith, 2008). Interestingly, Lewis' arguments about industrial and agricultural development in West Indian islands some years later can be seen as being ignored. This is surely evident with the low allocations to the agricultural sector over the period under review in the Trinidad economy. The result of this low level of investment is reflected in the low contribution by the agricultural sector to the country's gross domestic product; averaged at less than $1 \%$ over the last five years. One can conclude there has been very little agricultural development in Trinidad over the years.

The phenomenon of the Dutch disease is evident in Trinidad and Tobago (Hosein \& Tewarie, 2004; Wenner, Bollers, \& Hosein, 2018) and the declining interest in agricultural production is evident by the aging farmers upon whom food production is dependent. Further, talented youth are steering away from agricultural education and farming activities in quest for educational pursuits and employment opportunities in better paid areas (Tripathi, Dixit, Singh, \& Yadav, 2018; Leavy \& Hossain, 2014; Thompson \& Russell, 1993). The access to free tertiary education in Trinidad \& Tobago has opened up opportunities for the rural youth who otherwise may have remained in agricultural production.

The make-work opportunities such as CEPEP, on the other side of the spectrum has created opportunities for the rural poor to gain employment into make-work programs which are not pegged to agricultural development. It can be argued that CEPEP would have contributed to the stagnant agricultural development. Any program which supports unskilled persons which attracts allocations of $55.8 \%$ of the agriculture allocation can be regarded as parasitic; taking key resources away from a productive sector to fund what can be considered to be unproductive economic activities. Since, this process continues unabated, it suggests that deagriculturalisation, described by Hosein and Gokool (2011) as "the decline in agriculture on account of the effects of the Dutch Disease" is being supported. 
The impact of a stymied sector is a rising food import bill. Williams and Smith (2008) indicated that "although food imports may alleviate such crises [food shortages] temporarily, they are not a viable solution for ensuring long-term food security given the huge fiscal deficits and balance of payments constraints facing many countries." Price volatility has a strong impact on the poor and on food importing countries (Capone et al., 2014). As such industrial development cannot be panacea for sustained access to food through food importation. The dependence on imported food will not ensure food security to any nation given the instability of global food production and prices. Additionally, the COVID-19 pandemic has demonstrated the urgent need for domestic food security across the globe. The dependence on imported food coupled with the high food importation bill for Trinidad and Tobago warrants additional support for national agricultural development.

Surplus revenue from industrial development can have a negative response for make-work programs such as CEPEP. These include negative impacts on work ethic and productivity, persons become less diligent in job searches and it compromises the long-term growth potential of the economy by stifling more dynamic sectors (Wenner, Bollers, \& Hosein, 2018). Employment creation through make-work program provides an artificial reduction in the national unemployment data. According to Watson (1994) make-work programs over the years have been used by some Caribbean governments as a 'political re-election gimmick', providing low-skilled jobs that 'keep workers in the poverty trap'. Notwithstanding this, make-work programs such as CEPEP will reduce poverty and address the challenges of poverty and social welfare in the Caribbean (Bowen, 2007). It is necessary, however, to ensure that these make-work programs also provide useful employment that can bolster weaker sectors such as the low performing agricultural sector in the case of Trinidad and Tobago. Lewis' development model of agriculture development alongside industrial development can be realized through make-work programs funded by revenues derived from the industrial sectors to support the long-term agenda of sustainable domestic food security. Recognizing that there is sufficient evidence from all data sources used in this study to support the benefits of CEPEP labour to agriculture to address the persistent shortages, we suggest that a portion of the current CEPEP personnel trained in agriculture and better remunerated, can be considered as a solution, even while government seeks to maintain mainstream CEPEP in its current format; given the social and political underpinnings at work to keep the status quo.

The CEPEP, make-work program, can be incorporated into the development agenda for agriculture in Trinidad and Tobago. While the program does offer a form of convenience employment for the poor and the reduction of the national unemployment data there are more benefits which can be derived to increase the agricultural work-force to improve domestic food security and reduce the food importation bill. It is apparent that there will be a need to critically assess and address the possible challenges related to work ethic, productivity, skill-set and overall remuneration to ensure the success of creating meaningful make-work employment for agricultural development. Make-work programs within the agricultural sector of Trinidad and Tobago can be a catalyst to simulate growth and sustainable economic development. One issue however, is the seasonality of farm work. Presently most production is done in the wet season under the rain-fed agricultural system. To provide sustainable employment in the farm sector, the modalities of production would have to be revised; this is a role for the government agency responsible for agriculture. It may be through revised policies, incentives, and a dedicated extension advisory service. A modernized agricultural system that promotes year-round food production, using water harvesting system for dry-season production as well as use of adoption of efficient water use technologies in greenhouse systems of production can ensure year-round production activities.

Historically, Trinidad and Tobago provided labor for farms in Canada each year. Although this is seasonal, the pay compensates. In Trinidad and Tobago, where the pay may be lower, sustained employment would have to be provided.

In conclusion, this study finds that it is an excellent opportunity to incorporate CEPEP employment into the agricultural workforce. It is in this regard that CEPEP can help the agricultural sector. It is a complex situation and finding the balance between sustaining employment and increasing food production would be the challenge. It is a common perception that the labor pool in CEPEP could simply be reallocated in agriculture but this is not automatic. It requires capacity building, a structured work program, retooling, and mentorship which include a possible re-evaluation of wage rates and consistency of employment. Moreover, social perception of the labor force captured in CEPEP is generally negative and associated with relatively low productivity, untrustworthy individuals and a misconception of the potential to grow the competencies and encourage equity across each strata of society. 


\section{Acknowledgements}

The authors wish to express gratitude to the ECIAF Librarian and staff of the University of Trinidad and Tobago for the support provided in sourcing archival information to support this study.

\section{References}

Becken, S., \& Lennox, J. (2012). Implications of a long-term increase in oil prices for tourism. Tourism Management, 33(1), 133-142. https://doi.org/10.1016/j.tourman.2011.02.012

Bowen, G. A. (2007). The challenges of poverty and social welfare in the Caribbean, Int J Soc Welfare, 16(2), 150-158. https://doi.org/10.1111/j.1468-2397.2006.00453.x

Braun, V., \& Clarke, V. (2006). Using thematic analysis in psychology, Qualitative Research in Psychology, 3(2), 77-101. https://doi.org/10.1191/1478088706qp063oa

Capone, R., El Bilali, H., Debs, P., Cardone, G., \& Driouech, N. (2014). Food Economic Accessibility and Affordability in the Mediterranean Region: An Exploratory Assessment at Micro and Macro Levels, Journal of Food Security, 2(1), 1-12. https://doi.org/10.12966/ajnfs.04.04.2014

Chand, R., \& Srivastava, S. K. (2014). Changes in the rural labor market and their implications for agriculture, Economic and Political Weekly, 49(10), 47-54.

Cresswell, J. W., \& Plano Clark, V. L. (2011). Designing and conducting mixed method research (2nd ed.). Thousand Oaks, CA: Sage.

Daly, J., Kellehear, A., \& Gliksman, M. (1997). The public health researcher: A methodological approach. Melbourne, Australia: Oxford University Press.

Denzin, N., \& Lincoln, Y. (1998). The landscape of qualitative research: theories and issues. Thousand Oaks, California: SAGE Publications, Inc.

Dolores, M., \& Tongco, C. (2007). Purposive sampling as a tool for informant selection. Ethnobotany Research \& Applications, 5, 147-158. https://doi.org/10.17348/era.5.0.147-158

Douglas, S (2007). CEPEP's 378M spree. Trinidad and Tobago Newsday. Retrieved from http://www.newsday. co.tt/news/0,50610.html

Government of the Republic of Trinidad and Tobago. (2015). Review of the Economy 2015. Port-of-Spain: The Ministry of Finance.

Government of the Republic of Trinidad and Tobago. (2018). Review of the Economy 2018-"Transformation". Port-of-Spain: Ministry of Finance.

Hosein, R., \& Gookool, R. (2011). Hydrocarbonm Export and Food Insecurity in a small Petroleum rich ecomony. Social and Economic Studies, 60(3\&4), 21-65.

Hosein, R., \& Tewarie, B. (2004). Dutch disease and Déjà vu: Policy Advice for the Trinidad and Tobago Economy in the wake of a second oil boom. West Indian Journal of Engineering, 26(2), 1-21.

International Monetary Fund. (2012). World economic outlook 2012. Retrieved from http://www.imf.org/external/ pubs/ft/weo/2012/02/pdf/text.pdf

Khan, A. (2014). IDB: T\&T's social programs Too Generous. Trinidad and Tobago Guardian Newspaper. Retrieved from http://www.guardian.co.tt/business/2014-08-24/idb-tt $\% \mathrm{E} 2 \% 80 \% 99 \mathrm{~s}-$ social-programs-too-generous

King, N. (2004). Using templates in the thematic analysis of texts. In C. Cassell \& G. Symon (Eds.), Essential guide to qualitative methods in organizational research (pp. 256-270). London: Sage Publications. https://doi.org/10.4135/9781446280119.n21

Krueger, R. A., \& Casey, M. A. (2000). Focus Groups. A Practical Guide for Applied Research (3rd ed.). Thousand Oaks, CA: Sage Publications.

Leavy, J., \& Hossain, N. (2014). Who wants to farm? Youth aspirations, opportunities and rising food prices (IDS Working Paper No. 439). Institute of Development Studies, Brighton. https://doi.org/10.1111/ j.2040-0209.2014.00439.x

Lewis, W. A. (1954). Economic development with unlimited supplies of labor. Manchester School of Economic and Social Studies, 22(2), 139-191. https://doi.org/10.1111/j.1467-9957.1954.tb00021.x

Miles, M. B., \& Huberman, A. M. (1994). Qualitative Data Analysis. Thousand Oaks, CA: Sage 
Naimi, L. (2007). Strategies for Teaching Research Ethics in Business, Management and Organisational Studies. The Electronic Journal of Business Research Methods, 5(1), 29-36. Retrieved from http://www.ejbrm.com

National Training Agency. (2015). Labor Market Survey. National Training Agency: Research and Development Department.

Olsen, W. K., Holborn, M., \& Haralambos, U. (2004). Triangulation in Social Research: Qualitative and Quantitative Methods Can Really Be Mixed. Developments in Sociology. Causeway Press.

Onwuegbuzie, A. J., Leech, N. L., \& Collins, K. M. (2010). Innovative Data Collection Strategies in Qualitative Research. The Qualitative Report, 15(3), 696-726. Retrieved from https://nsuworks.nova.edu/tqr/vol15/ iss $3 / 12$

Rice, P., \& Ezzy, D. (1999). Qualitative research methods: A health focus. Melbourne: Oxford University.

Sorias, L. (2014). Phase out CEPEP. Trinidad Express Newspaper. Retrieved from http://www.trinidadexpress. com/news/Phase-out-CEPEP-273677121.html

Thompson, J. C., \& Russel, E. B. (1993). Beliefs and intentions of counselors, parents and students regarding agriculture as a career choice. Journal of Agricultural Education, 34(4), 55-63. https://doi.org/10.5032/ jae.1993.04055

Timmer, P. (2005). Agriculture and Pro-poor Growth: An Asian Perspective. SSRN. Retrieved from https://doi.org/ $10.2139 /$ ssrn. 984256

Tocco, B., Davidova, S., \& Bailey, A. (2012). Key Issues in Agricultural Labor Markets: A Review of Major Studies and Project Reports on Agriculture and Rural Labor Markets. Working Paper 20, Factor Markets Project.

Tong, A., Flemming, K., McInnes, Oliver, E. S., \& Craig, J. (2012). Enhancing Transparency in Reporting the Synthesis of Qualitative Research: ENTREQ. BMC Medical Research Methodology, 12, 181. https://doi.org/10.1186/1471-2288-12-181

Tripathi, H., Dixit, V. B., Singh, S., \& Yadav, R. (2018). Measuring the attitude of rural youth towards farming: an exploratory study of Haryana. Haryana Vet., 57(2), 183-188.

Venkatesh, P. (2013). Recent trends in rural employment and wages in India: Has the growth benefitted the agricultural labors? Agricultural Economics Research Review, 26(Conference Issue), 13-20.

Watson, H. A. (1994). Beyond nationalism: Caribbean options under global capitalism. In H. A. Watson (Ed.), The Caribbean in the global political economy (pp. 225-231). Boulder, CO, Lynne Rienner Publishers.

Wenner, M., Bollers, E., \& Hosein, R. (2018). The Dutch Disease Phenomenon and Lessons for Guyana: Trinidad and Tobago's Experience. International Development Bank (IDB) Technical Report 1470. https://doi.org/ $10.18235 / 0001203$

Williams, T. O., \& Smith, R. (2008). Rethinking Agricultural Development: the Caribbean Challenge. Paper presented at the XL (40th) Annual Monetary Studies Conference, November 11-14, 2008, Basseterre, Saint Kitts.

World Bank. (2008). Agriculture for Development. World Development Report. Washington, D.C.

\section{Copyrights}

Copyright for this article is retained by the author(s), with first publication rights granted to the journal.

This is an open-access article distributed under the terms and conditions of the Creative Commons Attribution license (http://creativecommons.org/licenses/by/4.0/). 